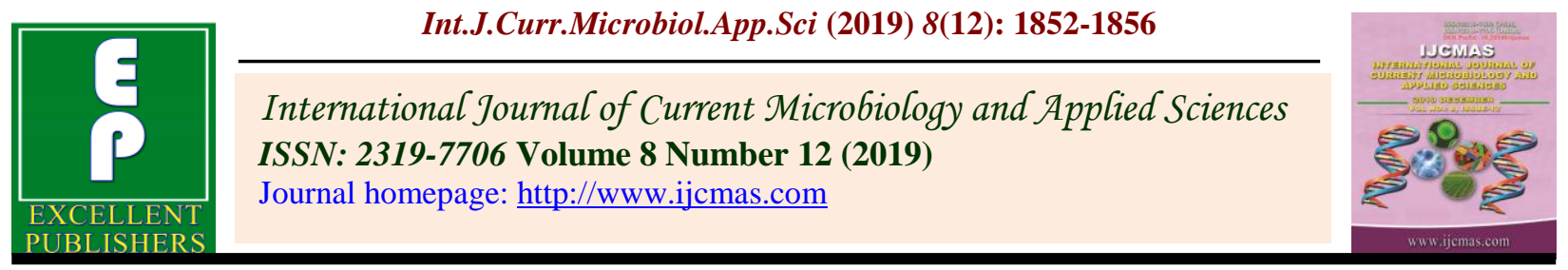

Original Research Article

https://doi.org/10.20546/ijcmas.2019.812.220

\title{
Effect of Dietary Supplementation of Nano Zinc Oxide (nZnO) on Growth Performance in Crossbred Calves
}

\author{
T. S. V. Anil ${ }^{1 *}$, Ch. Venkata Seshaiah ${ }^{2}$, P. Ashalatha ${ }^{2}$ and K. Sudhakar ${ }^{2}$ \\ ${ }^{1}$ Veterinary Assistant Surgeon, Rajamahendravaram Division, East Godavari District, \\ Andhra Pradesh, India \\ ${ }^{2}$ Department of Livestock Production Management, NTR College of Veterinary Science, Sri \\ Venkateswara Veterinary University, Gannavaram, Andhra Pradesh, India \\ *Corresponding author
}

Keywords

Crossbred calves,

Cost economics,

Growth

performance, Nano

Zinc,

Supplementation

Article Info

Accepted:

15 November 2019

Available Online:

10 December 2019

\section{A B S T R A C T}

An experiment was conducted to investigate the effect of dietary supplementation of nano zinc oxide $(\mathrm{nZnO})$ on growth performance in crossbred calves. Twenty four crossbred calves of about 6 months age were randomly divided into four groups (Control, Treatment1, Treatment2 and Treatment3) of six calves each. The Control (C) group was fed with basal diet, T1 was supplemented with $25 \mathrm{ppm} \mathrm{ZnSo} 4, \mathrm{~T} 2$ and $\mathrm{T} 3$ were supplemented with $5 \mathrm{ppm}$ and $10 \mathrm{ppm} \mathrm{nZnO}$ respectively, along with the basal diet. The results affirm that the body weight gain $(\mathrm{kg})$ and average daily gain $(\mathrm{g} / \mathrm{day})$ were significantly $(\mathrm{P}<0.01)$ higher in $\mathrm{T} 3$ group followed by $\mathrm{T} 2$ and $\mathrm{T} 1$ and lowest in control group. The cost per kg weight gain (Rs) was lowest in $\mathrm{T} 3$ followed by $\mathrm{T} 2$ and $\mathrm{T} 1$ while highest in the control group. The present study concluded that economic growth rate can be achieved by supplementing $\mathrm{nZnO}$ at $10 \mathrm{ppm}$ level in crossbred calves.

\section{Introduction}

Zinc, as a trace mineral caters to several needs of the animal directly or indirectly which supports the functions like growth, skin health, hair and hoof growth, wound healing, cell division and reproduction etc. The performance of growing animals is severely affected even upon a minute deficiency of trace minerals and Zinc is not an exception. Bovines require around 33milligrams per kilogram per animal of zinc in diet and the normal serum $\mathrm{Zn}$ concentration is between 0.7 and $1.3 \mathrm{~g} / \mathrm{ml}$. However, the soil in several parts of India in general and Andhra Pradesh, in particular, were reported to be deficient (Nagalakshmi et al., 2009) which makes the fodder, zinc deficient. To avoid Zn deficiency, 
the common practice is to add conventional zinc sources, over and above the recommended level where zinc lacks storage reserve in the body. Conventional forms of zinc are poorly soluble which attribute to their lower bioavailability is another drawback. In this scenario, finding an alternative source of zinc which can address zinc deficiency in animals is a challenging task where the concept of "formulation of least cost ration" adds further weight to it.

Nano engineered product, the nano zinc oxide (nZnO), a new form of zinc metal has been designed by using the principles of nanotechnology where, the size, shape and crystalline structure (Swain et al., 2016) of the metal are manipulated by various methods of preparation. It is noteworthy that these minerals in nano form come with the characteristic property of large surface area, particle size in the range of 1-100nm which accounts for sui generis property of better bioavailability in biological systems (Bulghavan et al., 2014). The major advantage with this property of nano zinc is that it could reduce the rate of inclusion in animal diet. Few workers across the world investigated dietary $\mathrm{nZnO}$ supplementation on growth performance in poultry and small ruminants. Many of the works reported a positive conclusion that inclusion of $\mathrm{nZnO}$ for conventional zinc showed an improvement in the feed intake (Ahmadi et al., 2013), growth rates (Mishra et al., 2014) and favourable FCR (Zhao et al., 2014; Sahoo et al., 2016) in various species. Hence, the study was taken up to investigate the effect of $\mathrm{nZnO}$ on growth performance in crossbred calves.

\section{Materials and Methods}

The present study was carried on 24 crossbred calves of 6 months age which were randomly distributed in four groups viz., Control(C) group where calves were fed with basal diet only, T1, T2 and T3 were supplemented with 25ppm $\mathrm{ZnSo} 4,5 \mathrm{ppm}$ and 10ppm of $\mathrm{nZnO}$ respectively, along with the basal diet. All calves were dewormed and deticked and kept in a well-ventilated house with concrete flooring having provision of individual feeding and watering. The experimental calves were fed with basal diet consisted of chopped Hybrid Napier and concentrate mixture feed as per their nutrient requirements. The composition of concentrate feed is charted in Table 1. The concentrate mixture was prepared with all the minerals except Zinc. The zinc content in the basal diet was found to be 26.24ppm which was tested using inductively coupled plasma atomic emission spectroscopy (ICP-OES). The experiment was performed for 90days. Conventional Zinc sulphate heptahydrate (HIMEDIA ${ }^{\circledR}$ ) and Nano $\mathrm{ZnO}$ 99.9\% pure (Nano Labs, Jharkhand, India) were weighed so that the requirements of all the calves are met individually in the respective groups and was mixed to a quantified amount of concentrate feed, stored in airtight containers separately and added to the daily dose of concentrate mixture. Feeding of concentrates followed by fodder was done daily in the morning and evening at a fixed time. Feed offered and feed left in the individual mangers were noted to obtain feed intake of the calf. The leftover concentrate mixture, if any was weighed. The indices of growth, feed intake and body condition score were taken at the beginning and every fortnight till the end of the experiment. An electronic platform weighing scale was used to record body weights. The body weights were obtained before calves were fed at the beginning of the experiment and every fortnight intervals until the end of the experiment. Bodyweight gain (kg) was obtained by subtracting initial body weight from the final bodyweight of the experimental calf. The average daily gain (g) was calculated by subtracting the initial body weight from the final body weight and dividing it by the 
number of days. The cost of feeding was calculated by considering the total quantity of feed consumed by the calves during the experimental period and the price of ingredients in the local market. The cost of conventional zinc sulphate was 100 rupees per 100 grams and that of Nano zinc oxide was 4000 rupees per 100 grams. The statistical analysis of data obtained was done by using SPSS.

\section{Results and Discussion}

The effect of dietary supplementation of nano zinc oxide (nZnO) on body weight gain in calves was presented in Table 2. Statistical analysis revealed that there was a significant difference $(\mathrm{P}<0.01)$ observed between the test groups in the body weight gain $(\mathrm{kg})$ of calves at the end of the experiment. The nano zinc supplementation at 10ppm showed higher $(\mathrm{P}<0.01)$ growth rates compared to the other groups which may be attributed to better uptake of nanoparticles of zinc in the gastrointestinal tract than the remaining groups (Mishra et al., 2014). Identical results were documented in poultry birds by Sahoo et al., (2016) wherein they found a statistically significant difference between the body weights in broilers when supplemented with inorganic, organic and nano sources of zinc.
Ahmadi et al., (2013) also indicated that the bodyweight (live) in birds fed on ZONPs included diets was significantly $(\mathrm{P}<0.05)$ higher than the remaining groups. In contrary to our study, the growth rate in buffalo bull calves (Jadhav, 2005) and crossbred calves (Mandal, 2004) were not affected when their diets were supplemented with 35 and 70 ppm conventional Zinc source. Similarly, Zaboli et al., (2013) also noted no significant difference in body weight gains among goat kids. The average daily gain (g/day) was also significantly $(\mathrm{P}<0.01)$ higher in the group supplemented with nano zinc @10ppm compared to the other groups. The results of the present experiment are relatable with the observations of Wang et al., (2017) and Hongfu et al., (2008) where the weaned piglets supplemented with Zinc oxide nanoparticles significantly increased average daily gain (ADG). In contradictory, Jadhav (2005) reported no significant change in ADG of calves. The total cost of feeding crossbred calves for 90days of the experimental period and the cost of feeding per kg weight gain are represented in Table 3. The results showed an increase in the mean cost of feeding during the entire experimental period. However, the cost (Rs) per $\mathrm{kg}$ weight gain was reduced in the groups supplemented with nano zinc oxide.

Table.1 Ingredient composition of concentrate feed used for experimental calves

\begin{tabular}{|c|c|}
\hline Ingredients & Parts (100) \\
\hline Maize & 40 \\
\hline $\begin{array}{c}\text { De-oiled rice bran } \\
\text { (DORB) }\end{array}$ & 18 \\
\hline Soybean meal & 30 \\
\hline Ground Nut cake & 5 \\
\hline Molasses & 4 \\
\hline Di-Calcium Phosphate & 2 \\
\hline Salt & 1 \\
\hline Total & $\mathbf{1 0 0}$ \\
\hline
\end{tabular}


Table.2 Initial and final body weights of crossbred calves in different groups

\begin{tabular}{|c|c|c|c|c|}
\hline & Control & Treatment 1 & Treatment 2 & Treatment 3 \\
\hline Initial body weight & $117.91 \pm 6.12$ & $115.66 \pm 7.67$ & $115.83 \pm 8.30$ & $116.25 \pm 7.51$ \\
\hline $\begin{array}{c}\text { Final body weight } \\
\text { (on 90 }^{\text {th }} \text { day) }\end{array}$ & $136.66^{\mathrm{d}} \pm 4.51$ & $150.91^{\mathrm{c}} \pm 8.65$ & $151.25^{\mathrm{b}} \pm 7.71$ & $155.91^{\mathrm{a}} \pm 8.05$ \\
\hline Weight Gain (kg) & $18.75^{\mathrm{d}} \pm 6.39$ & $35.25^{\mathrm{c}} \pm 4.64$ & $37.54^{\mathrm{b}} \pm 0.87$ & $39.67^{\mathrm{a}} \pm 0.73$ \\
\hline ADG (g) & $208.33^{\mathrm{d}} \pm 11.51$ & $391.67^{\mathrm{c}} \pm 12.32$ & $417.11^{\mathrm{b}} \pm 10.54$ & $440.78^{\mathrm{a}} \pm 11.43$ \\
\hline
\end{tabular}

Table.3 Effect of nano zinc oxide supplementation on the total cost of feeding Crossbred calves

\begin{tabular}{|c|c|c|c|c|}
\hline & Control & Treatment 1 & Treatment 2 & Treatment 3 \\
\hline $\begin{array}{c}\text { Mean cost of feeding per calf } \\
\text { for 90days }\end{array}$ & $4276.3 \pm 6.08$ & $4284.97 \pm 4.35$ & $4288.7 \pm 11.13$ & $4324.39 \pm 2.70$ \\
\hline $\begin{array}{c}\text { Cost of feeding per kg weight } \\
\text { gain (rupees) }\end{array}$ & $150.04 \pm 3.04$ & $140.18 \pm 10.12$ & $118.30 \pm 2.82$ & $110.64 \pm 2.58$ \\
\hline
\end{tabular}

The lowest and highest cost per kg weight gain was noticed in groups supplemented with $10 \mathrm{ppm}$ nano zinc oxide and control groups, respectively. Though the mean cost of feeding was high in the groups supplemented with nano zinc oxide, the growth and weight gains were higher in $\mathrm{nZnO}$ supplemented groups which resulted in reduced cost per $\mathrm{kg}$ weight gain. The results of the present study are consistent with Lina et al., (2009) who observed a downscale in cost of broiler production when they were supplemented with nano-zinc oxide.

From the study, it can be concluded that the economic growth rate of crossbred calves can be achieved by supplementing $\mathrm{nZnO}$ at $10 \mathrm{ppm}$ level in the feed.

\section{Acknowledgement}

The authors are thankful to Sri Venkateswara Veterinary University, Tirupati for providing necessary support and facilities to carry out the study.

\section{References}

Ahmadi, F., Ebrahimnezhad, Y., Sis, N. M. and Ghiasi, J. (2013). The effects of zinc oxide nanoparticles on performance, digestive organs and serum lipid concentrations in broiler chickens during the starter period. Int $J$ Biosci. 3(7): 23-29.

Bunglavan, S. J., Garg, A. K., Dass, R. S. and Sameer, S. (2014). Use of nanoparticles as feed additives to improve digestion and absorption in livestock. Livestock Research International, July-September.2(3): 3647.

Hongfu, Y. B. Z. (2008). Effects of Nano-ZnO on growth performance and diarrhoea rate in weaning piglets [J]. China Feed. 1(008).

Jadhav, S. E. (2005). Effect of Different Levels and Sources of Zink Supplementation on Growth, Nutrient Utilization, Rumen Fermentation, Blood Biochemical and Immune Response in Male Buffalo Calves (Doctoral dissertation, IVRI).

Lina, T., Jianyang, J., Fenghua, Z., Huiying, R. and Wenli, L. (2009). Effect of nano-zinc oxide on the production and dressing performance of broiler. Chinese Agricultural Science Bulletin. 2(003). 
Mandal G P 2004 Effect of Zinc Supplementation on Growth Metabolic Profile and Immunity in Crossbred Calves. PhD Thesis submitted to the Indian Veterinary Research Institute.

Mishra, A., Swain, R. K., Mishra, S. K., Panda, N. and Sethy, K. (2014). Growth performance and serum biochemical parameters as affected by nano zinc supplementation in layer chicks. Indian J. Anim. Nutr. 31(4): 384-388.

Nagalakshmi, D., Reddy, M.R. and Prasad, M.R. (2009). Mineral status of dairy animals in high altitude and tribal zone of Andhra Pradesh. In: NAAS Proceedings of ANA world conference, 14th $-17^{\text {th }}$ February 2009, New Delhi.

Sahoo, A., Swain, R. K., Mishra, S. K., Behura, N. C., Beura, S. S., Sahoo, C. and Jena, B. (2016). Growth, Feed conversion efficiency and carcass characteristics of broiler chicks fed on inorganic, organic and nano zinc supplemented diets. Animal Science. 10(1): 10-18.

Swain, P. S., Rao, S. B., Rajendran, D.,
Dominic, G. and Selvaraju, S. (2016). Nano zinc, an alternative to conventional zinc as animal feed supplement: A review. Animal Nutrition. 2(3): 134-141.

Wang, C., Zhang, L., Su, W., Ying, Z., He, J., Zhang, L. and Wang, T. (2017). Zinc oxide nanoparticles as a substitute for zinc oxide or colistin sulfate: Effects on growth, serum enzymes, zinc deposition, intestinal morphology and epithelial barrier in weaned piglets. PloS one. 12(7): e0181136.

Zaboli, K., Aliarabi, H., Bahari, A. A. and Abbas, A. K. R. (2013). Role of dietary nano-zinc oxide on growth performance and blood levels of mineral: A study on in Iranian Angora (Markhoz) goat kids. Journal of Pharmaceutical and Health Sciences. 2(1):19-26.

Zhao, C. Y., Tan, S. X., Xiao, X. Y., Qiu, X. S., Pan, J. Q. and Tang, Z. X. (2014). Effects of dietary zinc oxide nanoparticles on growth performance and antioxidative status in broilers. Biological trace element research. 160(3): 361-367.

\section{How to cite this article:}

Anil, T. S. V., Ch. Venkata Seshaiah, P. Ashalatha and Sudhakar, K. 2019. Effect of Dietary Supplementation of Nano Zinc Oxide (nZnO) on Growth Performance in Crossbred Calves. Int.J.Curr.Microbiol.App.Sci. 8(12): 1852-1856. doi: https://doi.org/10.20546/ijcmas.2019.812.220 